\title{
Functional morphology and biomechanics of the cynodont Trucidocynodon riograndensis from the Triassic of Southern Brazil: Pectoral girdle and forelimb
}

Téo Veiga De Oliveira and Cesar Leandro Schultz

Acta Palaeontologica Polonica 61 (2), 2016: 377-386 doi:http://dx.doi.org/10.4202/app.00171.2015

Non-mammalian cynodonts provide insights on several points about mammalian evolution, such as the postural change and locomotory advances within the group. Unfortunately, complete skeletons of Triassic cynodonts are rather uncommon and where more complete specimens are found they can offer a global vision on some traits not available from partial specimens. This is the case of the cynodont Trucidocynodon riograndensis , from the Triassic of Brazil, that has preserved its forelimbs providing some insights into locomotory properties. The movements between interclavicle and clavicle must have been limited, as such as those occurring between the latter and the scapulocoracoid although the long acromion process of this should have permitted a greater degree of freedom. Some of the more significant movements were those on the shoulder joint, in which the maximum adduction should have been ca. $35^{\circ}$ relative to the parasagittal plane and the greater abduction ca. $55^{\circ}$. The maximum adduction occurred when the humerus was in the more retracted position during stride and the variation in the adduction/abduction should have been significant to the limb posture during its recovery stroke. The long olecranon and the distal overlapping between radius and ulna suggest the predominance of simple flexion/extension on the forearm without significant pronation/supination. The poorly preserved hand suggests that Trucidocynodon could have evolved a slight semidigitigrad condition in its forelimbs. All these features give to this cynodont an important role in the evolution of the mammalian locomotory properties indicating that some features, such as the possibility of greater humeral adduction, evolved early in cynodont lineage.

Key words: Cynodontia, Trucidocynodon, limb posture, biomechanics, Triassic, Carnian, Brazil.

Téo Veiga de Oliveira [teovoli@yahoo.com.br], Divisão de Mamíferos do Museu de Zoologia da UEFS, Departamento de Ciências Biológicas, Universidade Estadual de Feira de Santana, Avenida Transnordestina s/n, Bairro Novo Horizonte, CEP 44036-900, Feira de Santana, Bahia, Brazil. Cesar Leandro Schultz [cesar.schultz@ufrgs.br], Departamento de Paleontologia e Estratigrafia, Instituto de Geociências, Universidade Federal do Rio Grande do Sul, Avenida Bento Gonçalves, 9500, Bairro 
Agronomia, CEP 91501-970, Porto Alegre, Rio Grande do Sul, Brazil.

This is an open-access article distributed under the terms of the Creative Commons Attribution License (for details please see creativecommons.org), which permits unrestricted use, distribution, and reproduction in any medium, provided the original author and source are credited.

Farif Full text $(955.0 \mathrm{kB})$ 